\title{
ENSINO REMOTO EM TEMPOS DE PANDEMIA: LEITURA E PRODUÇÃO DE TEXTOS PARA CRIANÇAS E JOVENS
}

\author{
READING AND TEXT PRODUCTION FOR CHILDREN \\ AND YOUTH
}

\author{
Sandra Trabucco Valenzuela' \\ Regina Celia Ruiz ${ }^{2}$
}

1 Doutora e Mestre em Letras pela Universidade de São Paulo (USP), com Pós-Doutorado em Literatura Comparada pela USP, Especialista em História da Arte e Cinema; é docente da FAM e membro do Grupo de Pesquisa Produções Literárias e Culturais para Crianças e Jovens da FFLCH-USP.

2 Mestre e Doutoranda em Literatura pela Universidade de São Paulo (USP), é docente do ensino Fundamental II e Médio da rede particular na cidade de São Paulo (SP) e membro do Grupo de Pesquisa Produções Literárias e Culturais para Crianças e Jovens da FFLCH-USP. 
RESUMO: O presente trabalho visa apresentar dois relatos de experiência a respeito do ensino da literatura e produção de textos, dentro do contexto transitório gerado pela pandemia provocada pelo Coronavírus. Crianças e jovens, no mundo inteiro, tiveram suas aulas presenciais suspensas, havendo a necessidade de adequação por parte de todos os envolvidos no processo ensino-aprendizagem ao ensino remoto - em especial dos professores -, adaptando as atividades para que estas funcionassem no novo modelo. O tema "morte" passou a compor parte do cotidiano e, desse modo, abordar um assunto tão difícil e que estava tão presente suscitou a necessidade de reflexões dentro das salas de aula virtuais. Promover a leitura e a produção de textos no contexto da pandemia trouxe a necessidade de estimular diálogos com os leitores, estabelecendo discussões sobre o significado da morte, sobre a dor e a saudade. Com foco nessas preocupações, o trabalho docente proposto para alunos do primeiro semestre do ensino superior, numa instituição pública do Estado de São Paulo, foi a produção de contos baseados em imagens criadas pelo fotógrafo senegalês Alun.be, em seu projeto imagético inspirado na África, que une o mundo virtual e a cultura africana, num processo de integração entre o passado mítico e o presente, pontuado pela tecnologia. Por sua vez, alunos do Ensino Fundamental II da rede particular de ensino da cidade de São Paulo produziram textos verbais e não-verbais, após reflexões e debates promovidos pela leitura de livros de Odilon Moraes, Viriato Correa e Beatriz Martín Vidal, estabelecendo relações que dialogam com questões existenciais em evidência no contexto atual. Pierre Lévy, Nelly Novaes Coelho, Didi-Huberman e Roland Barthes ofereceram os caminhos que iluminam as práticas concretizadas durante este período de aulas síncronas, voltadas para a formação do leitor e produção de textos.

PALAVRAS CHAVES: Escrita criativa; Produção de textos; Narrativas transmídia; Formação de leitores; Ensino na pandemia

ABSTRACT: This paper presents two experience reports on the teaching of literature and text production within the transitional context generated by the Coronavirus pandemic. Students all over the world had their classroom lessons suspended, and there all those involved in teaching-learning process had to adapt their activities to a new model. The theme of "death" became part of everyday life and, thus, to approach such a difficult subject that was so present raised the need for discussion and reflection within the virtual classrooms. Promoting reading and text production in the context of pandemics brought the need to stimulate dialogues with the readers, establishing discussions about the meaning of death, about grief and longing. Focusing on these concerns, the teaching work proposed to first-semester college students, in a public institution in the state of Sao Paulo, the composition of short stories based on images created by the Senegalese photographer Alun be, in his African-inspired photo project, which unites the virtual world and the mythical past of African culture, in a process of integration between the mythical past and the present, punctuated by technology. In turn, students from the 
Elementary School II of the private educational system of the city of São Paulo produced verbal and non-verbal texts after reflections and debates promoted by the reading of books by Odilon Moraes, Viriato Correa and Beatriz Martín Vidal, establishing relations that dialogue with existential questions in evidence in the current context. Pierre Lévy, Nelly Novaes Coelho, Didi-Huberman and Roland Barthes offered the paths that illuminate the practices carried out during this period of synchronous classes, focused on reader training and text production.

KEYWORDS: teaching literature; creative writing; text production; transmedia narratives; reader training 


\section{INTRODUÇÃO}

No dia 11 de março de 2020, a Organização Mundial da Saúde (OMS) elevou o estado da contaminação mundial pelo novo Coronavírus ao patamar de "pandemia de Covid-19", doença facilmente transmissível, como tantas viroses semelhantes a gripes e resfriados, e que representa um perigo quando atinge idosos, imunodeprimidos de qualquer idade ou, ainda, pessoas comuns sem qualquer problema de saúde aparente. O contágio é rápido e invisível, muitos não apresentam qualquer sintoma, no entanto, podem disseminar a doença. Nos casos mais graves, a intubação por um longo período superlotou os hospitais em todo o mundo:

O termo "pandemia" se refere à distribuição geográfica de uma doença e não à sua gravidade. A designação reconhece que, no momento, existem surtos de COVID-19 em vários países e regiões do mundo. (Organização Panamericana de Saúde, mar. 2020)

Esse cenário de insegurança demandou ações, entre as quais está a determinação do governo de São Paulo (assim como de outras localidades) para que novas formas de se ministrar aulas, em todos os níveis de ensino, fossem organizadas, pois o isolamento social era uma necessidade.

No Estado de São Paulo, foro desta pesquisa, a Secretaria Estadual da Educação homologou, através da Resolução Seduc, de 18/3/2020, a aprovação do ensino a distância:

A Secretaria Estadual da Educação homologou a deliberação aprovada pelo Conselho Estadual que permite que atividades realizadas por meio de EAD (ensino a distância) aos alunos do ensino fundamental e médio, durante o período de suspensão das aulas, possam ser computadas como dias letivos. O documento foi publicado no Diário Oficial no dia 19 de março (Secretaria da Educação do Governo do Estado de São Paulo, 02/07/2020)

Neste novo contexto, em face da importância de não se interromper as atividades educacionais vinculadas à instituição escolar, o ensino remoto tornou-se a única opção viável e segura capaz de permitir a continuidade dos estudos. A implementação 
dessa modalidade educacional, no entanto, estava (e ainda está) longe de ser simples, acessível para todos e passível de ser orientada por uma metodologia de trabalho já pensada e adequada às novas vias de intercomunicação.

O ensino remoto exigiu um processo de aprendizagem e adaptação para alunos, famílias dos alunos e profissionais do ensino. A nova experiência demandou a adequação dos professores, das escolas e de todos os profissionais que, de alguma forma, estão envolvidos na consecução das ações pedagógicas.

Por outro lado, a disparidade social e econômica que compõe a estrutura da sociedade brasileira acentuou-se ainda mais no caso do ensino, ampliando a brecha existente entre aqueles que navegam pelo mundo digital e aqueles que não têm acesso à Internet e nem às ferramentas relacionadas. A crise econômica aguçada pela pandemia gerou desemprego e a queda da renda das famílias. A educação, dentro desse contexto, foi diretamente impactada:

Segundo dados do Fundo das Nações Unidas para a Infância (Unicef), a evasão escolar no Brasil atinge 5 milhões de alunos. Durante a pandemia de Covid-19, esses números aumentaram em $5 \%$ entre os alunos do ensino fundamental e $10 \%$ no ensino médio. Para os que ainda estão matriculados, a dificuldade foi de acesso, com 4 milhões de estudantes sem conectividade. (Agência Câmara de Notícias, 06/10/2021).

O relatório divulgado pelo Fundo das Nações Unidas pela Infância (Unicef) indicava um aumento da evasão escolar durante a pandemia de Covid-19, apontando uma cifra superior a 667 mil alunos fora das escolas no Estado de São Paulo, em 2020. A referida pesquisa, feita em parceria com a União Nacional dos Dirigentes Municipais de Educação (UNDIME), observou a ampliação nas faixas etárias mais prejudicadas pela evasão. Em termos comparativos, no ano de 2019, o índice de abandono foi de $2 \%$, entre crianças de 6 a 10 anos; porém, em 2020, o índice saltou para 9,2\%, sendo as crianças e adolescentes de 6 a 17 anos os grupos mais prejudicados. ${ }^{3}$

3 Informações extraídas do portal de notícias G1: Disponível em https://gl.globo.com/sp/sao-paulo/ noticia/2021/07/23/evasao-escolar-dispara-durante-a-pandemia-e-cerca-de-670-mil-alunos-ficam-sem-estudar-em-sp-aponta-relatorio.ghtml Acesso em: 30 out. 2021. 


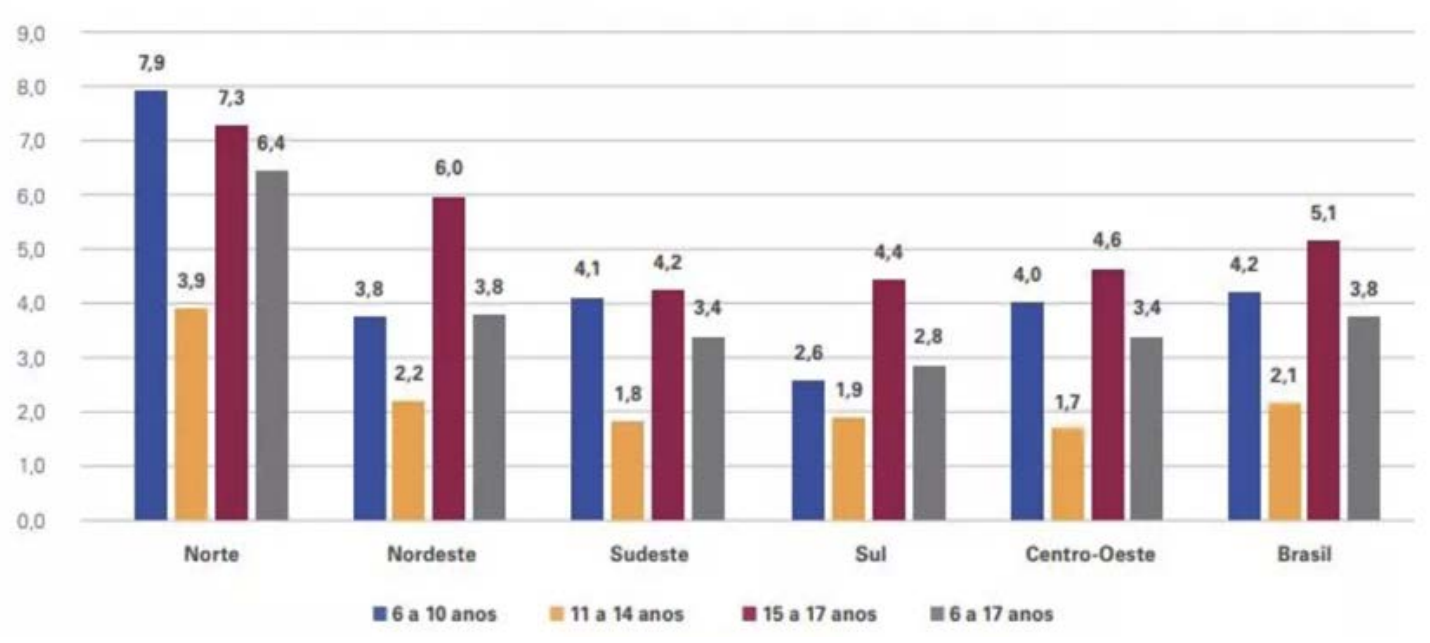

Figura 1. Distribuição de crianças e adolescentes de 6 a 17 anos com Educação Básica incompleta que não estão frequentando a escola, por Grandes Regiões. Outubro, 2020(\%) Fonte: IBGE. Pesquisa Nacional por Amostra de Domicílios - Pnad Covid-10, 2020.

O isolamento social e a suspensão das aulas presenciais estimularam o desenvolvimento das aulas remotas. Contudo, surgiu o novo desafio: a conectividade e a capacitação do professorado e demais profissionais da educação para trabalhar a distância, usando ferramentas digitais.

Problemas como acesso à internet, equipamentos, treinamento e capacitação necessária para o ensino remoto tornaram-se preocupações centrais: em 2020, cerca de 5,5 milhões de crianças e adolescentes permaneceram sem acesso à educação, de acordo com os levantamentos realizados pelo Unicef e Cenpec Educação. ${ }^{4}$

Apresenta-se, na sequência, dois relatos de experiência a respeito do ensino de literatura e produção de textos dentro do contexto gerado pela pandemia. O primeiro relato refere-se à experiência no Ensino Superior e o segundo relato aborda as atividades realizadas com alunos do Ensino Fundamental II.

4 Disponível em: https://glo.bo/3vYZSWf Acesso em: 30 out. 2021. 


\section{RELATO DE EXPERIÊNCIA COMO DOCENTE DO ENSINO SUPERIOR NA MODALIDADE REMOTA}

Meu nome é Sandra e leciono no Ensino Superior há mais de 30 anos, para jovens cuja faixa etária varia, em sua maioria, entre 17 e 25 anos. Durante o período do isolamento social, atuei como docente do curso superior tecnológico de Design de Mídias Digitais, numa instituição pública e gratuita, em uma faculdade particular de São Paulo, durante os anos de 2020 e 2021. Minha primeira experiência com ensino EAD teve início em 2005, com disciplinas oferecidas $100 \%$ online, assíncronas, o que constitui uma proposta bem diferente das aulas online síncronas.

Relato, a seguir, a experiência pessoal e profissional desenvolvida durante as aulas de Interpretação e Produção de textos.

\section{A PRODUÇÃO DE TEXTOS VERBAIS E NÃO VERBAIS}

Desde os tempos antigos até as tentativas da vanguarda, a literatura se afaina na representação de alguma coisa.

O quê? Direi brutalmente: o real.

(Barthes, Aula, 1977, p.20)

O momento de retomada das atividades pedagógicas online foi difícil para todos os envolvidos no processo, já que, num curto espaço de tempo, houve a necessidade de entender e interpretar o novo contexto de ensino-aprendizagem, readequar-se, aprender a utilizar ferramentas online, rever as aulas já preparadas, visto que as suas apresentações nem sempre se mostravam eficientes no ensino remoto. Todos tiveram de compreender rapidamente e analisar as diversas situações que se instauravam numa sala virtual: nem todos os alunos possuíam câmera, microfone, computador ou aparelhos que permitissem a conectividade; nem todos possuíam um espaço propício para ter aulas; nem todos contavam ou conseguiam a colaboração para criar um lugar para ter aulas. Por outro lado, muitas famílias enfrentavam situações dolorosas relacionadas à perda de pessoas queridas vitimadas pela Covid-19; enfrentavam o 
desemprego, a redução de salários; era necessário lidar com um aumento dos casos de depressão, ansiedade, falta de atenção e outros transtornos intensificados pelo distanciamento social, pela dor da perda, pela solidão e por situações inusitadas e impensáveis, dadas em função da pandemia e do afastamento social.

Ao entrar numa sala de aula virtual, coube ao professor gerenciar situações múltiplas, realidades e emoções imprevisíveis e que eram compartilhadas à distância, através da tela do computador. O que até então era apenas uma ficção científica, arrebata a dimensão do real, superando qualquer distopia ficcional gerando dor, isolamento e sofrimento.

Repentinamente, todos os participantes do processo pedagógico foram lançados ao mundo virtual: o ciberespaço substituiu o espaço físico da sala de aula. Nas palavras de Pierre Lévy (2018):

O ciberespaço (que também chamarei de "rede") é o novo meio de comunicação que surge da interconexão mundial dos computadores. O termo especifica não apenas a infraestrutura material da comunicação digital, mas também o universo oceânico de informações que ela abriga, assim como os seres humanos que navegam e alimentam esse universo. Quanto ao neologismo “cibercultura”, especifica aqui o conjunto de técnicas (materiais e intelectuais), de práticas, de atitudes, de modos de pensamento e de valores que se desenvolvem juntamente com o crescimento do ciberespaço. (LÉVY, 2018, p.16)

Assim, em virtude do distanciamento social, deu-se o salto para o ciberespaço como alternativa única possível para a continuidade das atividades escolares e de formação profissional. Não houve muito tempo para reflexão, pois o contexto cobrava ações imediatas: para sair do ensino presencial e entrar no ensino remoto foi preciso um esforço concentrado para elevar a capacidade de sistemas e redes das instituições, implementar e/ou ampliar o uso de softwares, propiciar a alunos e professores a conectividade para concretização do processo.

Embora a cibercultura esteja presente em todos os âmbitos da vida contemporânea, entender sua dinâmica dentro da modalidade de ensino remoto instiga a uma reflexão nos termos de Pierre Lévy (2018): 
as artes da cibercultura reencontram a grande tradição do jogo e do ritual. O que é mais contemporâneo retorna assim ao mais arcaico, à própria origem da arte em seus fundamentos antropológicos. A essência das grandes rupturas ou dos verdadeiros "progressos" não é, por sinal [...] retornar paradoxalmente ao começo? No jogo como no ritual, nem o autor nem a gravação são importantes, mas antes o ato coletivo aqui e agora. (Lévy, 2018, p.157)

Ao refletir sobre as palavras de Pierre Lévy sobre o encontro da "tradição do jogo e do ritual", podemos pensar que o mesmo aconteceu no processo da sala de aula virtual: ruptura, jogo e ritual se conjugam num ato coletivo de compartilhar e produzir conhecimento.

Havia uma necessidade de falar, expressar sentimentos, contar qual era a realidade vivida e percebida, mas também havia a vontade de desconectar-se. Um dos caminhos que escolhi foi a retomada do repertório de leituras unido ao componente constitutivo do cotidiano. Solidão, fuga da realidade e medo foram alguns dos sentimentos resgatados em leituras anteriores que, em geral, pertenciam ao âmbito da ficção científica, livros de aventura ou romances de fantasia.

Uma das atividades propostas foi a leitura de Alice no País das Maravilhas, de Lewis Carroll, na versão para a língua portuguesa composta por Augusto de Campos, e a leitura de O Corvo (The Raven), de Edgar Allan Poe (lançado originalmente em 1845), nas versões de Machado de Assis e de Fernando Pessoa (2019). O tom lúgubre perpassado pelo medo do desconhecido marca o tom do poema de Poe, como é possível constatar na primeira estrofe traduzida por Fernando Pessoa:

\footnotetext{
Numa meia-noite agreste, quando eu lia, lento e triste, Vagos, curiosos tomos de ciências ancestrais, E já quase adormecia, ouvi o que parecia $\mathrm{O}$ som de alguém que batia levemente a meus umbrais. "Uma visita", eu me disse, "está batendo a meus umbrais. É só isto, e nada mais". (POE, 2019, Trad. Fernando Pessoa)
}

Na sequência, houve o estudo e trabalho sobre a intertextualidade e a transposição do texto literário para outras linguagens, como a da produção audiovisual, a 
exemplo da adaptação o poema para o terceiro episódio da segunda temporada da série de animação Os Simpsons, intitulado “No dia das bruxas", de 1990.

Passamos, então, a refletir sobre a construção de personagens, suas características psicológicas, físicas e seus percursos narrativos. Trouxe a discussão sobre o mito e a jornada do herói, proposta por Joseph Campbel em O herói de mil faces (1999) e a obra de Christopher Vogler, a Jornada do Escritor (1997), inspirada em Campbell.

Contudo, minha proposta de produção textual pretendia traçar uma linha capaz de unir ficção e realidade, marcada naquele momento pandêmico por tantas variáveis.

Foi então que conheci o Project Alun.be, cujo lema é: "A arte é uma ponte entre o imaginar e o ser." ${ }^{\prime 5}$

Alun.be é um fotógrafo nascido no Senegal e que propõe a captação de imagens observando um grande contraste entre o presente e as possibilidades da realidade virtual. Como tema principal, Alun.be vale-se de imagens de pessoas e sua condição humana, sua relação com o espaço. As imagens suscitam uma reflexão sobre a realidade contemporânea, sobre a junção entre presente, passado e futuro, que possibilita leituras criativas e sugere temas que abordam o humano: mitos, fé, criação, poder, autoconhecimento, visão e percepção que ultrapassam os limites da realidade.

As imagens de Alun.be trazem a possibilidade de compor histórias, personagens e cenários que, ao mesmo tempo são nossos contemporâneos, resgatam o passado mítico ou buscam no futuro alternativas visionárias.

Desse modo, as imagens de Alun.be foram usadas como ponto de partida para a produção de narrativas e vídeos que permitissem aos alunos sonhar um futuro diferente.

A realidade vivida no momento mais crítico da pandemia trouxe como principais temas o medo, a morte e suas metáforas (morte do convívio social, saúde, sonhos, esperanças, rituais e reuniões) e a necessidade de se fazer ouvir e de ultrapassar as amarras da realidade.

5 Fotos utilizadas neste trabalho de produção textual estão disponíveis em https://www.alunbe. com/edification\#0 Acesso 30 out. 2021. 


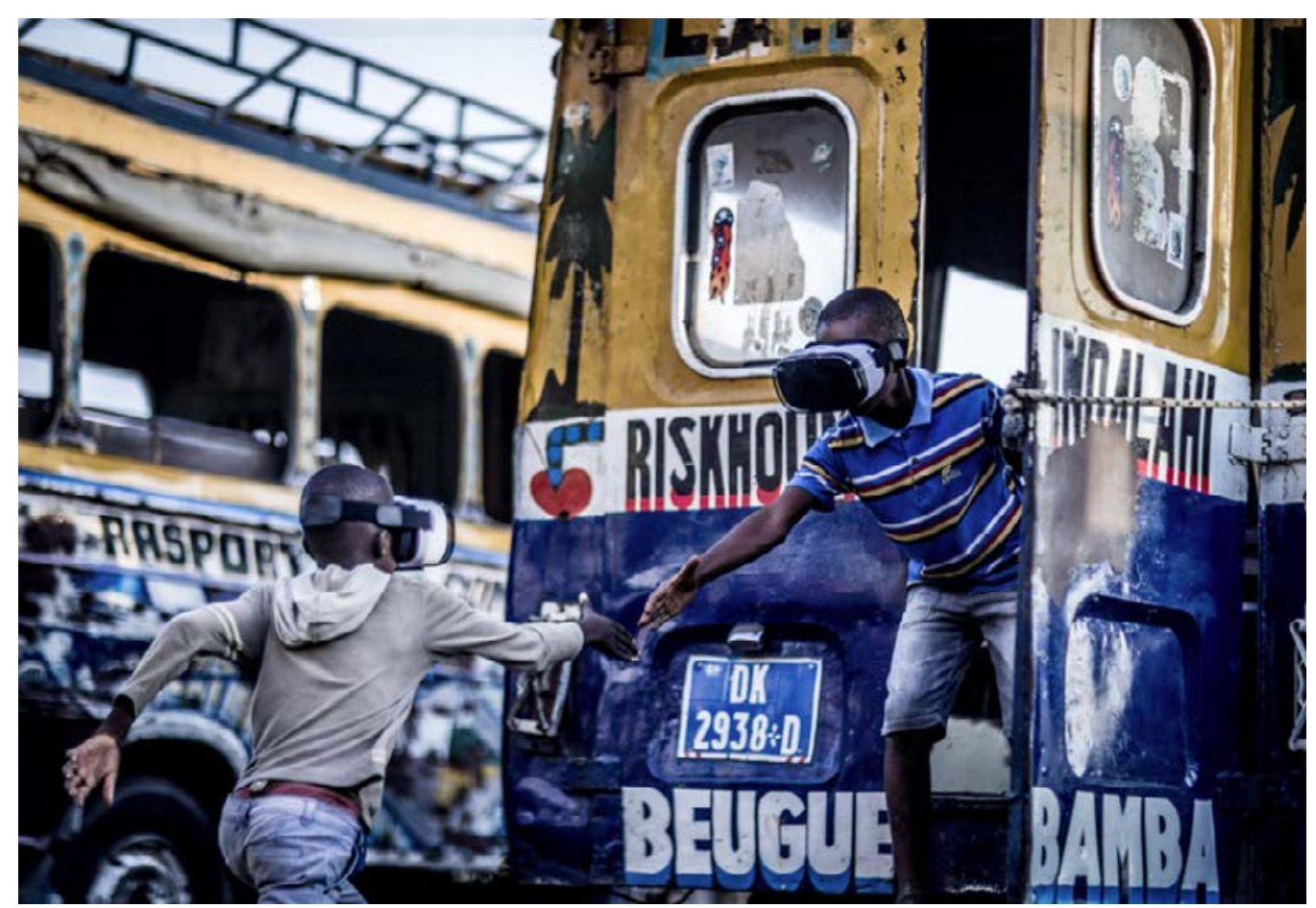

Figura 2. Foto de Alun.be intitulada Parentesco, série Edificação.

Fonte: https://www.alunbe.com/edification\#5

O trabalho de produção textual foi proposto como uma criação coletiva, pois envolvia texto escrito, imagens, narração e produção de um vídeo entre 4 e 8 minutos no total, incluindo os créditos. Como primeiro passo, cada grupo deveria selecionar a foto do Project Alun.be que mais lhe interessasse, considerando a coleção Edificação. ${ }^{6}$

$\mathrm{Na}$ aula seguinte, em salas virtuais separadas, cada grupo realizava um exercício de brainstorm (chuva de ideias) para conceber o caminho narrativo que seria proposto, retomando elementos já estudados, como a jornada do herói e a construção de personagens. Como docente, cabia a mim a orientação e o estabelecimento de diálogos intertextuais que enriquecessem a narrativa. O processo de criação do texto é um momento fundamental, pois implica discutir a imagem, ouvir o outro, compartilhar ideias até atingir um consenso sobre o caminho criativo a ser seguido.

Após a escrita, todos os grupos deveriam gravar a história em vídeo, inserindo um

6 Project Alun be, coleção Edificação https://www.alunbe.com/edification\#0 Acesso em 30 out. 2021. 
narrador e, se desejassem, também poderia haver vozes de personagens. Por fim, as narrativas seriam apresentadas em vídeo, através da plataforma Youtube, para toda a turma.

A figura 2, exposta acima, estimulou a narrativa intitulada Crianças de Ibejis, que conta uma história de dois irmãos que vivem num mundo distópico, devastado pela "hierarquia social que corrompe os legados e destrói famílias". A opção criativa voltou-se para abordar a despedida em função da morte.

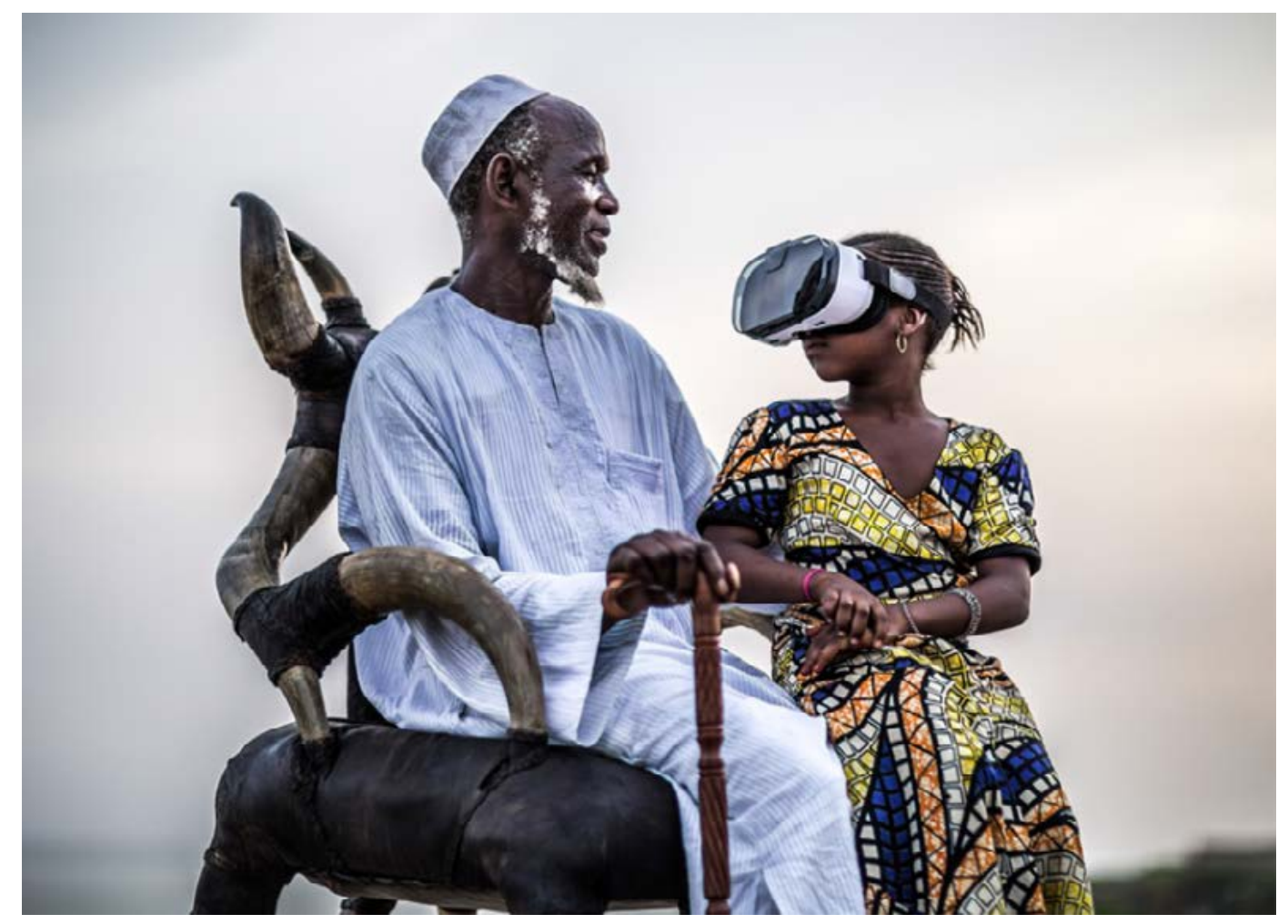

Figura 3. Foto de Alun.be intitulada Ethos, série Edificação.

Fonte: https://www.alunbe.com/edification\#1

Os contos produzidos pelos alunos giraram em torno a temas relacionados com mitos, espiritualidade e escapismo, constituindo uma aberta fuga da realidade, busca por uma sociedade alternativa, que prezasse pela união em detrimento da solidão; muitos falaram da morte como um processo de transformação. Alguns títulos foram: O jogo, O caminho perdido, Por trás de seus olhos, O último leitor, Travessia, Senhor do tempo, O despertar de um deus, Passagem para o passado e Mono No Aware, entre outros realizados no primeiro ano da pandemia (2020/1 e 2020/2). 
Nesta perspectiva, vem à tona o pensamento de Didi-Huberman (2011), ao afirmar a importância da experiência da realidade e sua relação com a experiência interior:

Compreende-se, então, que uma experiência interior, por mais "subjetiva", por mais "obscura" que seja, pode aparecer como um lampejo para o outro, a partir do momento em que encontra a forma justa de sua construção, de sua narração, de sua transmissão (DIDI-HUBERMAN, 2011, p.135).

O conto Mono No Aware trouxe a história de Cali, uma jovem descendente de indianos, que "carregava a sutileza da Deusa". Cali, uma cientista de grande capacidade intelectual, conheceu Rosa, uma ativista negra, com quem dividia um apartamento durante sua permanência no MIT. Ambas se viram em meio ao conflito causado pela morte de mais um cidadão negro por um policial branco, numa citação à morte por sufocamento de George Floyd ${ }^{7}$, em 25 de maio de 2020. O conto aborda a ferida histórica e social do racismo em meio à revolta. Cali entra num transe durante a meditação e volta no tempo. Encontra Martin Luther King, em 1961, que discursava para multidões. O final é poético: alvejada e diante de todos, Cali transforma-se numa flor de lótus.

Abaixo, as figuras 4, 5, 6 e 7 oferecem uma pequena mostra do processo criativo escolhido para desenvolver a narrativa. A personagem Cali é desenhada diante de nossos olhos, numa opção de revelar o processo de produção da imagem. Cali surge e se transforma, ao final, em flor de lótus, que simboliza, com suas oito pétalas, a harmonia cósmica, o espírito, a mente e a pureza, a sabedoria e o conhecimento, o amor e a compaixão. Esses significados variam de acordo com a coloração da flor. $\mathrm{Na}$ imagem que ilustra o conto, a flor é translúcida, permitindo assim imbuir todos os significados na caracterização da personagem Cali. Sobre a simbologia da flor de lótus, Chevalier e Gheerbrant (2006) afirmam que:

7 Mais informações sobre a morte de George Floyd estão disponíveis em: https://www.nytimes. com/article/george-floyd.html e em https://noticias.uol.com.br/reportagens-especiais/george-floyd-como-negro-morto-pela-policia-inspira-hoje-luta-antirracista/\#pagel Acessos em 30 out. 2021. 
Do Mediterrâneo à Índia e à China, sua importância simbólica de manifestações tão variadas, se deriva, tanto no plano profano como no sagrado, desta imagem fundamental. [...] Entretanto, as espiritualidades indianas ou budistas interpretarão num sentido moral a cor imaculada do lótus, abrindo-se intacta por cima da nódoa do mundo (Chevalier e Gheerbrant, 2006, p.558)

\section{Mono No Aware}

"Naquela manhã de 04 de abril, o mundo perdeu um pedaço importante, aquele que nos conecta 'a fantasia, à poesia, à música, porque a arte é a própria existência. Mas, é preciso às vezes mergulhar em si mesmo ou se afastar para ter a real dimensão da necessidade que temos da arte que existe nos detalhes de ser. "

Figura 4. Mono No Aware, 1ª imagem do vídeo, com o texto introdutório.

Martin Luther King foi morto no dia 04 de abril de 1968.

Fonte: https://bit.ly/3kWZPpq Acesso em 30 out 2021.

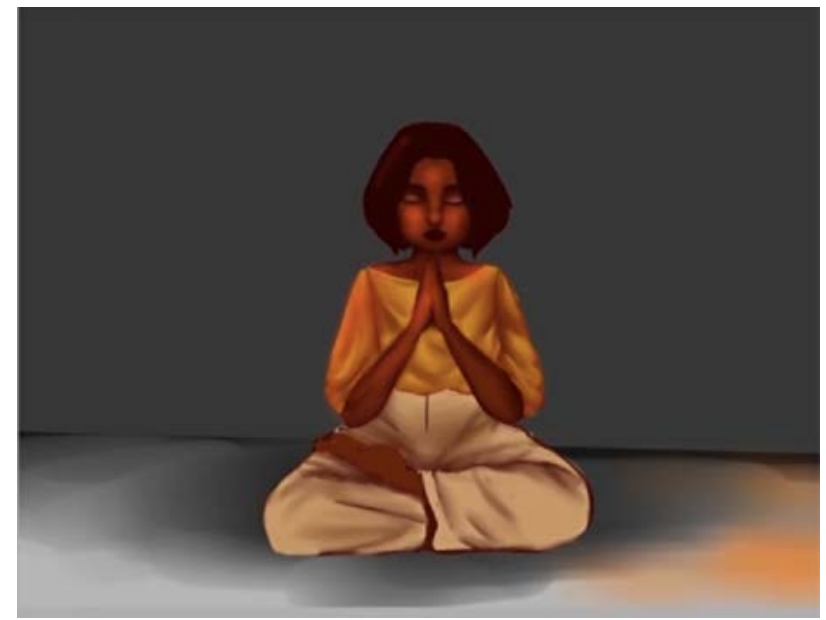

Figura 5. Mono No Aware em construção (1)

Fonte: https://bit.ly/3kWZPpq Acesso em 30 out 2021. 




Figura 6. Mono No Aware em construção (2)

Fonte: https://bit.ly/3kWZPpq Acesso em 30 out 2021.

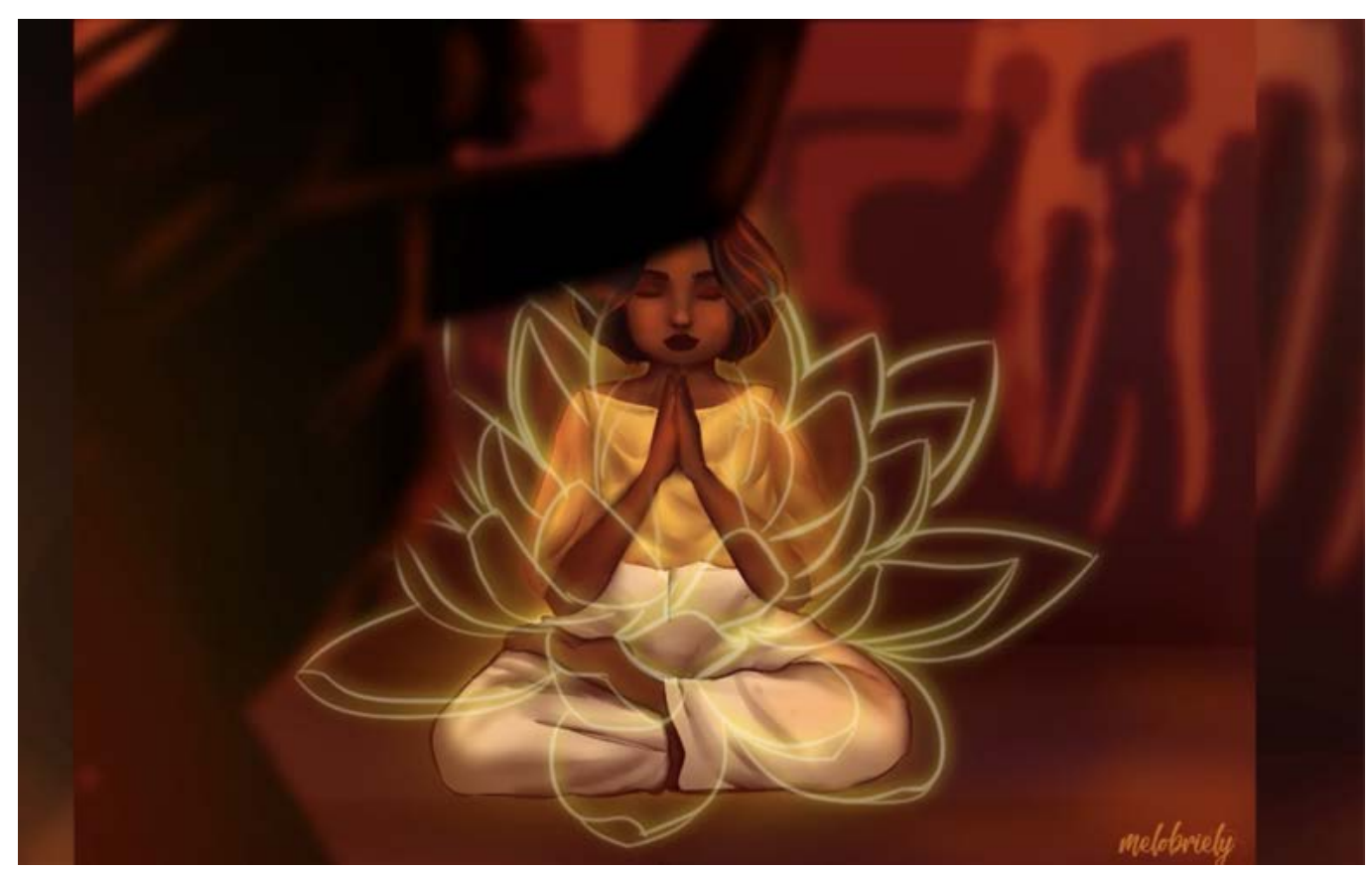

Figura 7. Mono No Aware.

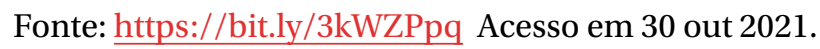




\title{
ENSINO DE LITERATURA PARA ESTUDANTES DO ENSINO FUNDAMENTAL II
}

\author{
O elemento genuinamente filosófico contido numa obra - seja de \\ arte, ciência, pensamento - é sua capacidade de ser desenvolvida, algo \\ que ficou sem ser dito, ou foi intencionalmente assim deixado, e que \\ se trata de saber encontrar e colher. (AGAMBEN, 2018, p.60)
}

Eu, Regina, leciono há mais de 30 anos. Comecei na rede municipal de ensino, no Ensino Fundamental II e EJA (Educação para Jovens e Adultos), depois passei para o Ensino Médio na rede particular, onde estou até hoje e, neste ano de 2021, tenho trabalhado com crianças da faixa etária de 10 a 12 anos, que estão nos $6^{\circ}$ e $7^{\circ}$ anos. Assim como no Ensino Superior, sair da sala de aula convencional e lecionar, sem sair de casa, pela tela do computador, não foi, a princípio, uma tarefa muito tranquila. Nós, professores, tivemos de aprender a lidar com o novo modelo de ensino. Em um primeiro momento, trabalhamos com o sistema assíncrono, gravando as aulas e postando os vídeos para que os alunos assistissem. Muitos problemas surgiram, pois sem um horário definido para a sequência de aulas, alunos e famílias tiveram dificuldades para se adaptar ao novo modelo. Com o tempo, com um suporte mais desenvolvido, passamos para as aulas síncronas, pelo Google Meet. No entanto, a nova realidade deixava os alunos muito dispersos; estavam em casa vivenciando um contexto bastante incomum. Os pais também começaram a trabalhar em casa. As famílias convivendo diariamente, unidas, sem saber exatamente como transcorreriam os próximos dias.

Logo no início da oficialização do estado de pandemia, foi preciso afastar-se dos idosos, ou seja, dos avós, tão importantes e presentes na vida de muitos desses alunos. Alguns perderam parentes e pessoas mais próximas, o que forçou as famílias e, em especial, as crianças, a entrarem em contato com um sentimento até então desconhecido por vários deles: a dor da morte. Durante as aulas, a dispersão e apatia eram visíveis. Recursos digitais foram utilizados para tentar unir o grupo, mesmo com a distância física.

Em uma aula síncrona, no $6^{\circ}$ ano, a intensidade dos problemas causados pelo período de pandemia ficou bastante evidente. Utilizei um texto para tratar do con- 
ceito e tipos de substantivos. Após leituras e discussões, pedi para que escrevessem, no chat, palavras ou frases que trouxessem exemplos de substantivos abstratos. $\mathrm{O}$ retorno dessa atividade acionou alguns alertas. O medo passava por quase todas as mensagens digitadas: o medo da morte, de perder os pais, medo de não reverem os amigos; falaram de saudades, amizade, solidão, tristeza, angústia. Visivelmente, a infância desses alunos começava a se abrir para caminhos inesperados.

Entendendo a literatura como uma forma de arte que humaniza, ao possibilitar novos olhares e reflexões no diálogo entre linguagens múltiplas, várias atividades foram oferecidas dando voz aos alunos para que compartilhassem suas questões existenciais, as que soavam como incômodos diários dentro do contexto de pandemia. Como diz Antonio Candido, em seu texto "O direito à literatura":

Entendo aqui por humanização (...) como um processo que confirma no homem aqueles traços que reputamos essenciais, como o exercício da reflexão, a aquisição do saber, a boa disposição para com o próximo, o afinamento das emoções, a capacidade de penetrar nos problemas da vida, o senso de beleza, a percepção da complexidade do mundo e dos seres, o cultivo do humor. A literatura desenvolve em nós a quota de humanidade na medida em que nos torna mais compreensivos e abertos para a natureza, a sociedade, o semelhante. (CANDIDO, 1995, p.180).

O primeiro caminho escolhido foi o trabalho com imagens. Orientei os alunos a fazerem uma leitura que transcendesse o visível, que olhassem além das formas e cores. O filósofo Didi-Huberman aponta sensações que uma imagem pode provocar:

Com frequência, quando pousamos nosso olhar sobre uma obra de arte, vem-nos a irrecusável sensação do paradoxo. O que nos atinge imediatamente e sem desvio traz a marca da perturbação como uma evidência que fosse obscura. Enquanto o que nos parece claro e distinto não é, rapidamente o percebemos, senão o resultado de um longo desvio (...) Pode-se (...) ficar insatisfeito com esse paradoxo. Querer-se-á ir adiante, saber mais, representar-se de forma mais inteligível o que a imagem diante de nós parecia ainda ocultar. (DIDI-HUBERMAN, 2013, p.9). 
Sendo assim, apresentei uma imagem inserida em uma campanha de adoção de animais. A proposta foi solicitar aos alunos que olhassem para a figura e fizessem relações com o próprio repertório e as sensações evocadas a partir dessa leitura.

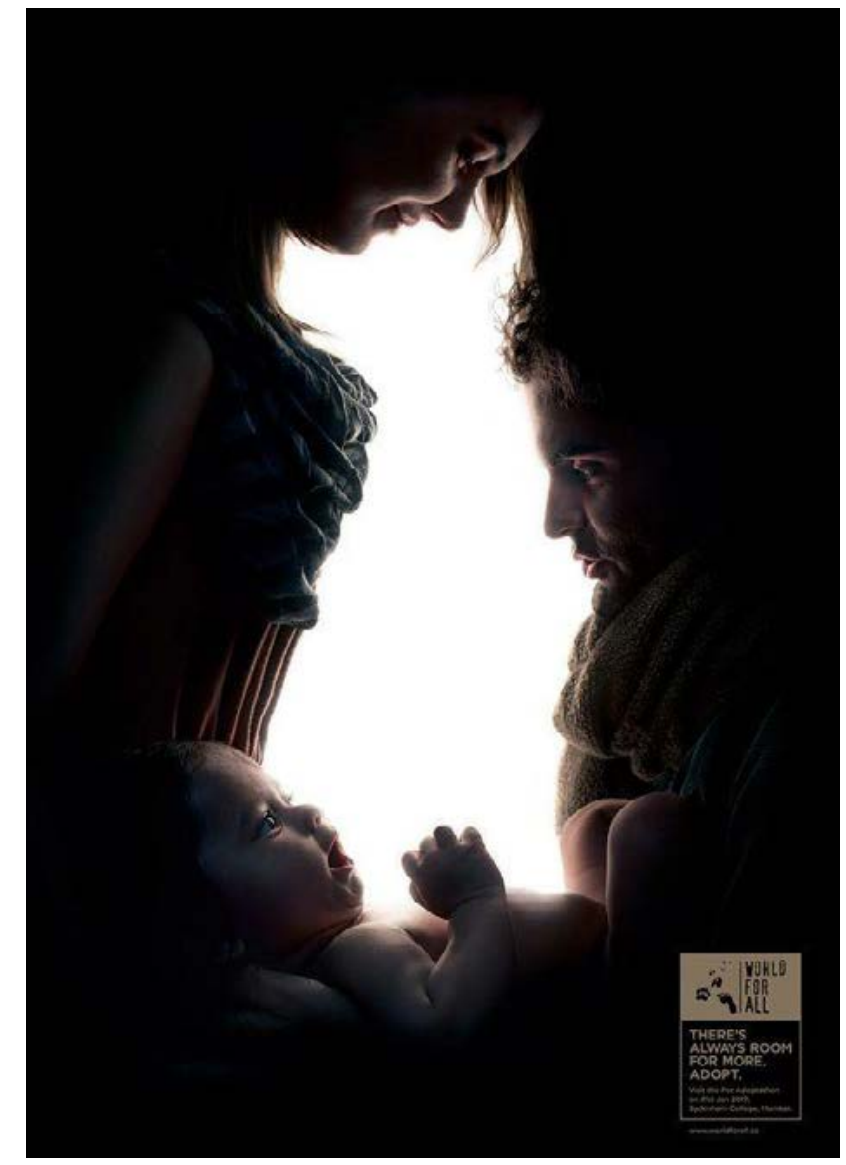

Figura 8. World For All Pet Adoption Campaign. McCann Worldgroup.

Fonte: Disponível em: https://digitalsynopsis.com/advertising/world-for-all-pet-adoption-optical-illusion/ Acesso em 30 out. 2021.

As considerações abordaram o contexto e união familiar, inserindo a presença de um animal de estimação; comentaram sobre atenção, carinho, cuidado; alguns fizeram relações com a Sagrada Família; outros disseram que sentiam certa angústia, tristeza, mas não sabiam explicar o motivo.

Após discutirmos sobre a leitura, hipóteses, simbologias e referências apontadas, pedi para que se manifestassem por meio de um texto que envolvesse o tema, as reflexões realizadas, e que também remetesse ao contexto de pandemia. Transcrevo, abaixo, um trecho de uma das produções: 
Depois da pandemia, Mariana e João estavam muito tristes. Muitos parentes tinham morrido e a vida deles não era mais a mesma. Então tiveram a ideia de adotar um bebê e um cachorro. Eles se tornaram uma bonita família de novo. E a doença nunca mais voltou! (Estudante do $6^{\circ}$ ano)

A imagem provocou um misto de sentimentos entre todos, atingindo o objetivo da proposta de externar as emoções, os sentimentos e terem voz para falarem a respeito dos incômodos causados pelo momento pandêmico.

Dando continuidade ao meu trabalho, apresentei uma pintura, agora para o $7^{\circ}$ ano, da artista espanhola Beatriz Martín Vidal, e convidei-os a fazer uma leitura detalhada da obra.

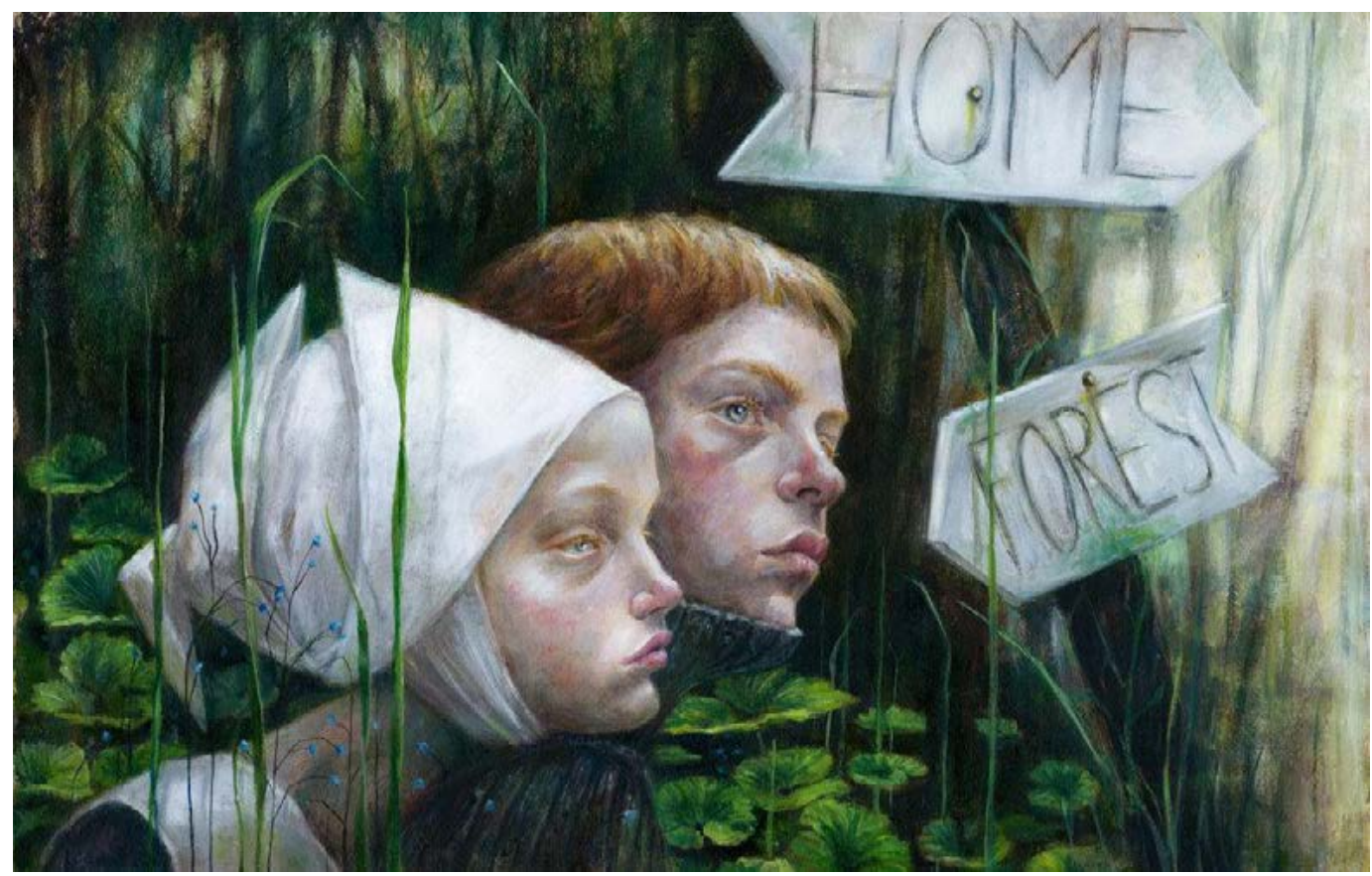

Figura 9. João e Maria, de Beatriz Martín Vidal.

Fonte: Beatriz Martín Vidal. Disponível em: https://www.beavidal.com/blog Acesso em 30 out. 2021.

Os alunos destacaram a presença de dois adolescentes, com olhares tristes, roupas de uma outra época; perceberam o espaço com muito verde, as setas indicando "casa" ou "floresta". Logo chegaram à história clássica, recontada na imagem de 
Beatriz Martín Vidal: “João e Maria”. Comentamos sobre o papel dos contos de fadas nos fios narrativos da história humana, tratando de todas as aflições existenciais que vivenciamos ao longo da vida, não importando época ou contexto. Retomamos o conto e levantei alguns questionamentos: quais foram as dificuldades e desafios que os dois irmãos enfrentaram na floresta? Como poderiam estabelecer relações com o momento em que estávamos vivendo? A atividade foi realizada na ferramenta Jamboard e apresento uma parte do resultado obtido:

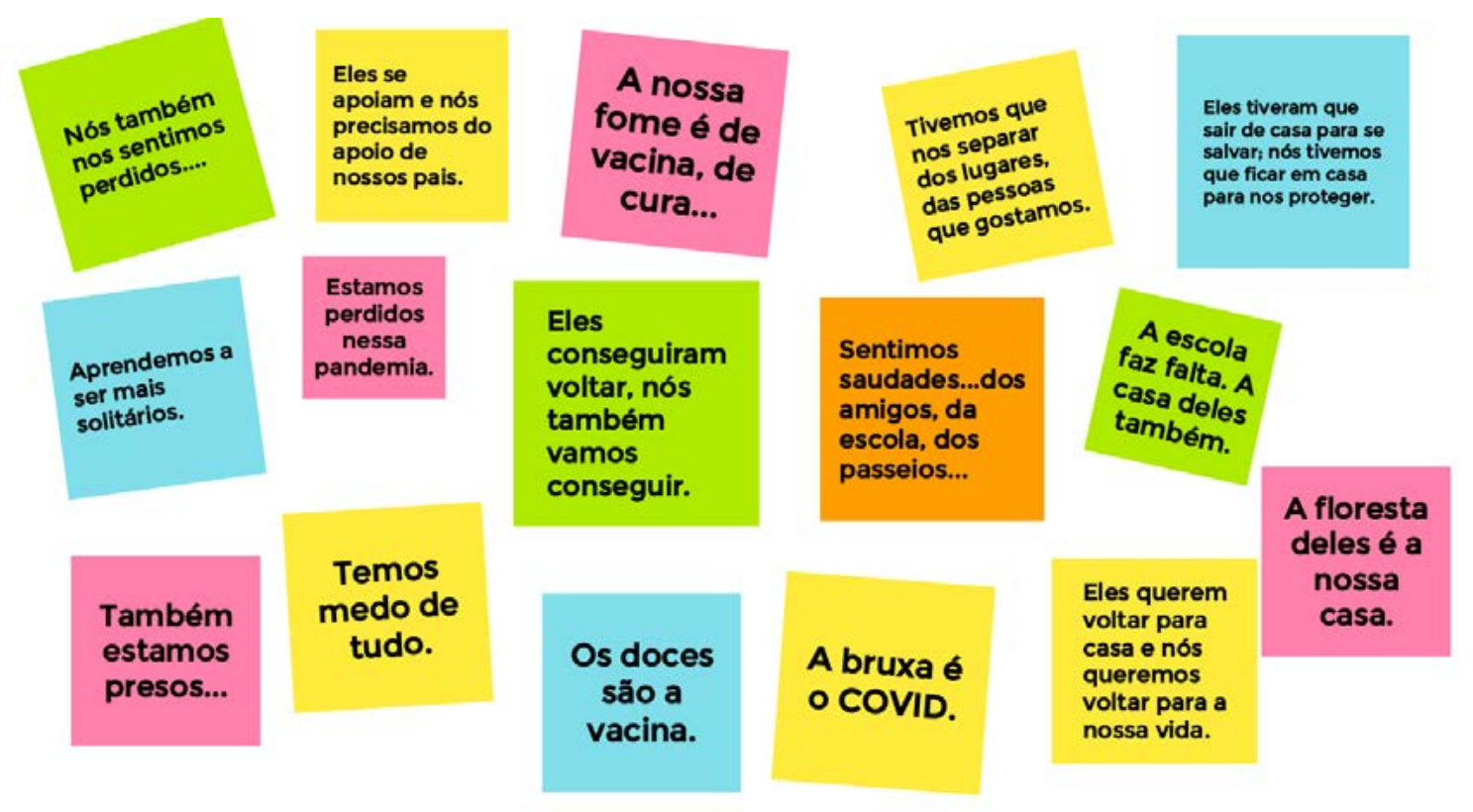

Figura 10. Jamboard.

Fonte: Arquivo pessoal.

Os alunos relacionaram as dores e sofrimento dos personagens com a própria vida, mas visualizaram momentos de esperança, já que, na narrativa, os dois irmãos conseguiram voltar para casa, após vencerem a bruxa. Para os alunos, o que precisavam era vencer a pandemia.

Continuando o percurso, no $6^{\circ}$ ano, trabalhamos com o livro Cazuza, de Viriato Correa, uma narrativa que ocorre em um pequeno vilarejo no Maranhão. Destaquei o capítulo "Pinguinho", que conta a história de um grupo de crianças que viam o dia da morte como uma oportunidade de grande diversão, pois era quando vinham pa- 
rentes e amigos que moravam mais distantes, e traziam os filhos, o que tornava as brincadeiras mais animadas. As crianças ficavam nos imensos quintais se divertindo, enquanto os adultos velavam a pessoa que havia falecido.

Um dos personagens, o Pinguinho, era um garoto doente, não tinha muita força para correr e brincar como os outros, mas seu papel era o de determinar as brincadeiras. Certo dia, ele passou muito mal, faleceu e, como todos, foi velado dentro de casa. Nesse momento, as crianças não ficaram lá fora brincando, velaram o amigo e, assim, compreenderam o que era a morte.

Ficamos todos em derredor do cadáver, sossegadinhos, tristes, silenciosos. Quando queríamos falar uns com os outros, era baixinho, aos cochichos, como se temêssemos perturbar a majestade da dor que nos afligia. Tínhamos, pela primeira vez, compreendido a morte. Era a primeira vez que ela nos tocava de perto. E, dali por diante, quando alguém morria no povoado, nunca mais enchemos de alaridos os terreiros e os quintais. Nunca mais fizemos de um dia de luto um dia de festa. Dali por diante, a morte ficou sendo para nós uma coisa séria, muito séria e muito triste. (CORREA, 2004, p.37)

Com essa leitura, o que mais marcou a conversa com a turma foi o amadurecimento dos personagens mediante a descoberta do sentido da morte; os alunos refletiram sobre o quanto podemos amadurecer ao enfrentarmos questões difíceis, e alguns relataram situações que estavam vivenciando no contexto familiar e os possíveis caminhos para a superação.

Como fechamento, após a leitura de "Pinguinho" e tudo o que refletimos a partir do tema, a minha proposta foi pedir uma ilustração que representasse o texto lido, em diálogo com a situação de pandemia. 


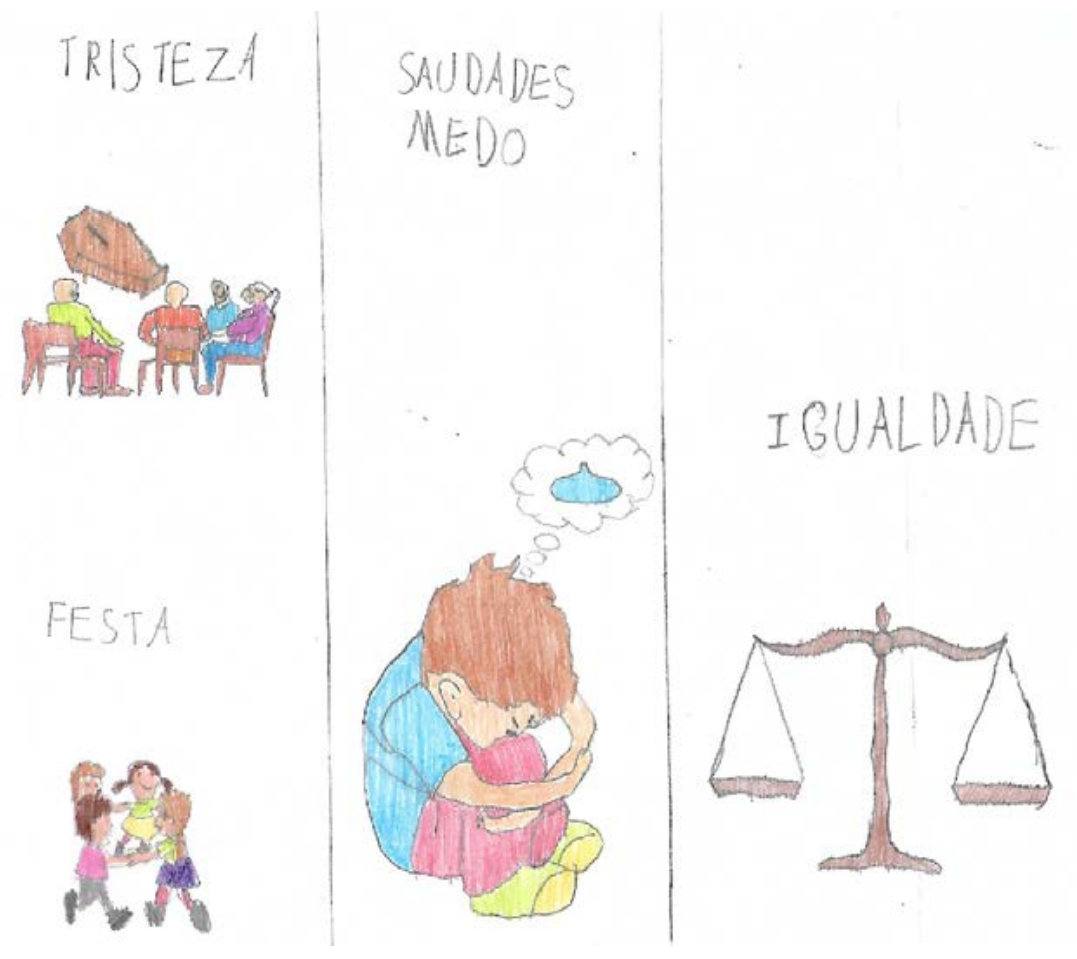

Figura 11. Ilustrações produzidas pelos estudantes.

Fonte: Arquivo pessoal.

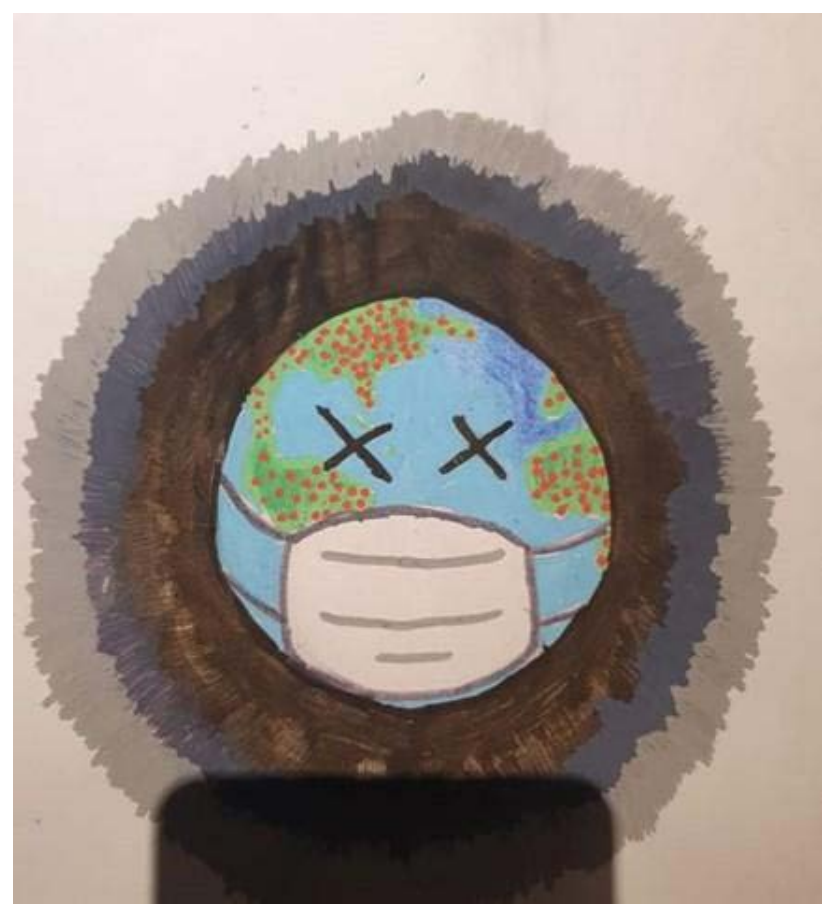

Figura 12. Ilustração produzida por um estudante.

Fonte: Arquivo pessoal. 
Voltando para o $7^{\circ}$ ano, apresentei uma nova proposta: a leitura do livro Olavo, de Odilon Moraes. O início da narrativa já nos fala muito do personagem: "Olavo era um menino triste. Não por algo que lhe faltasse, nem qualquer chance perdida. Olavo era simplesmente triste, como outros são felizes na vida" (MORAES, 2018, s/p). Trata-se da história de um menino triste e solitário que recebe um presente deixado em sua porta, mas chega a pensar que teriam deixado no lugar errado, pois, não acreditava que alguém pudesse se importar com ele. No livro, a cor predominante é o tom marrom. Quando o garoto recebe o presente, ocorre a chegada do azul, uma fresta na janela que começa a invadir a sua vida. Odilon Moraes trabalha o estado de espírito do garoto, tratando a tristeza, a solidão, a alegria e a esperança com a presença e troca das cores.

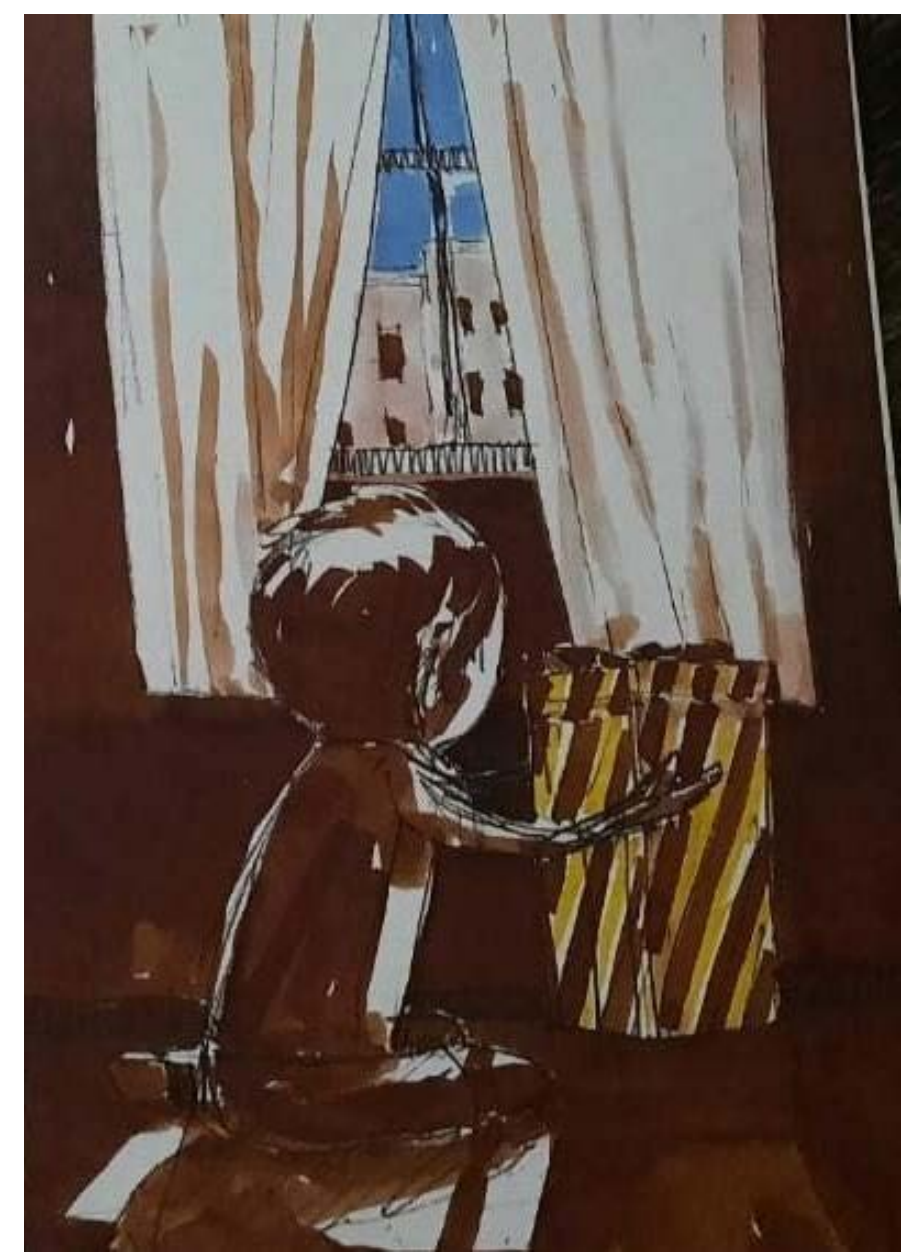

Figura 13. Ilustração do livro Olavo, de Odilon Moraes.

Fonte: MORAES, 2018. 
Após intensas reflexões sobre a interação do verbal e o não verbal, que se decifram em pistas de linguagens híbridas, os alunos começaram a apontar os entrelaçamentos da obra de Odilon Moraes com o momento pandêmico. Para isso, foi realizada uma atividade comparativa na ferramenta Padlet:

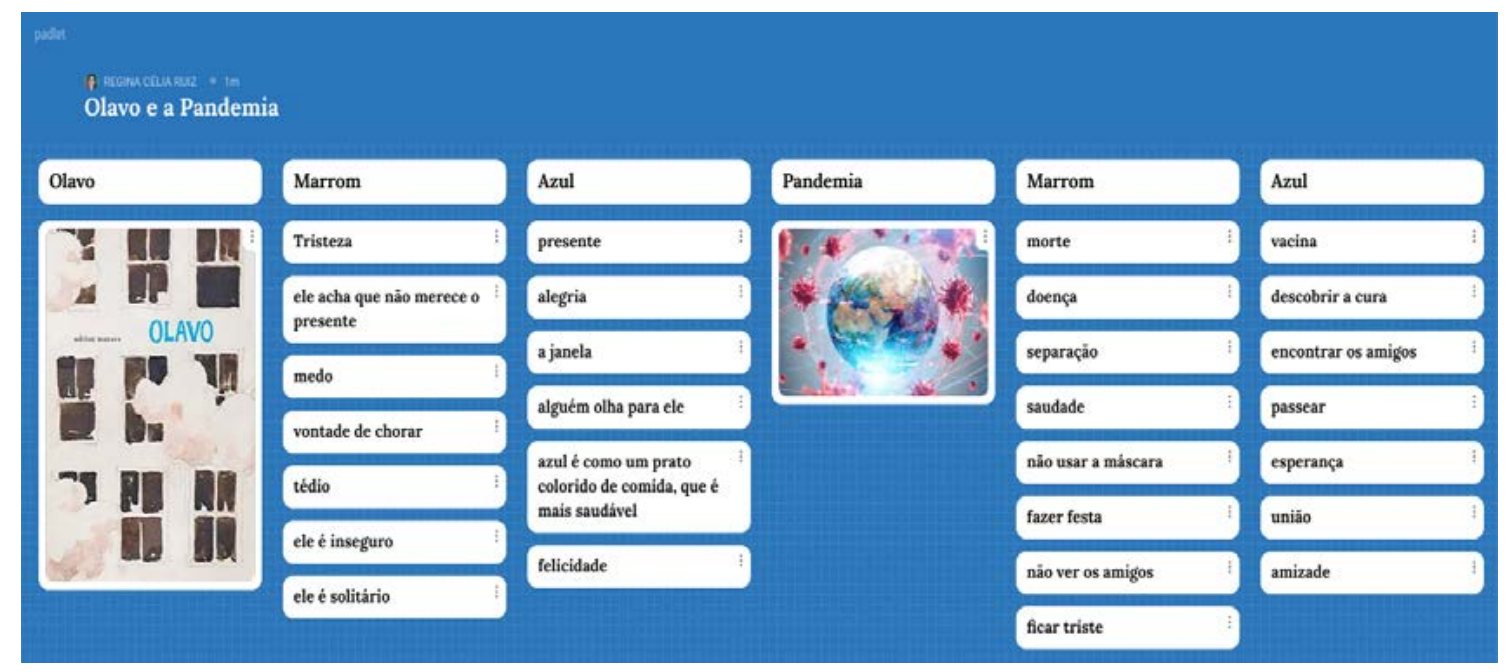

Figura 14. Padlet.

Fonte: Arquivo pessoal.

As cores da narrativa de Olavo foram o ponto de partida para que os alunos estabelecessem conexões em poucas palavras. O que era marrom e azul na história de Olavo? E o que era marrom e azul no contexto de pandemia? Após a leitura das múltiplas linguagens do texto, uma conclusão foi a representação da cor azul, com sua capacidade de metamorfosear a tristeza em sentimentos mais positivos, como a alegria e a esperança, uma síntese do que precisavam diante do contexto vivido.

Outras ações têm sido promovidas, ao longo desse período, para aprendermos a extrair algum aprendizado das situações difíceis por meio de reflexões e partilhas. No segundo ano de pandemia, em 2021, o colégio implementou um sistema em que todo o material didático passou a ser digital, incluindo a entrega de um Chromebook para cada aluno.

Essas atividades realizadas com os $6^{\circ}$ e $7^{\circ}$ anos, do Ensino Fundamental II, foram as escolhidas para apresentar neste artigo. Todo o percurso realizado, desde o início da pandemia, foi intenso e contribuiu para que os alunos tivessem uma real 
percepção de todas as mudanças que estão acontecendo, não somente ao redor de si, mas também envolvendo o mundo.

\section{CONSIDERAÇÕES FINAIS}

Em 2019, o mundo foi surpreendido com o avanço da doença provocada pelo coronavírus. A vacina, que chegou tarde para muitas das vítimas fatais, é o único sinal de esperança para que a doença possa ser controlada. A Covid-19 afetou não somente a área da saúde, mas também todos os setores da sociedade, em especial o da Educação, tema deste artigo. As redes particulares e públicas de ensino, de todos os níveis, precisaram de muitas adequações para que os anos letivos de 2020 e 2021 pudessem ter continuidade, tentando cumprir os planejamentos e conteúdo de cada ano e série.

Um dos maiores desafios foi a adequação ao novo modelo de ensino que se precisava adotar: o ensino remoto. Professores, alunos e família viram-se diante de uma nova sala de aula, sem as costumeiras carteiras e lousas, mas, cada um, dentro de uma tela de computador. De uma hora para outra, a escola estava dentro da casa de cada aluno, e cada aluno estava dentro da casa de cada professor. Por outro lado, no ensino superior, o home office tornou-se presente e compartilhava o foro da sala de aula.

O desafio foi imenso. Culturalmente, as instituições de ensino sempre tiveram o seu espaço próprio. Ir à escola, fazer parte de um grupo, ter o contato físico, aprender a viver socialmente integram a formação escolar de cada indivíduo. Mas, diante do inesperado, tivemos de nos adaptar. Para as redes públicas, o desafio foi ainda maior. Diante de um sistema dotado de escassos recursos tecnológicos, no que diz respeito tanto às instituições de ensino, quanto às dificuldades de acesso para professores e estudantes, assumir o novo modelo digital colocou à prova a fragilidade e deficiências presentes num modelo educativo que, embora inserido numa sociedade tecnológica, ainda vive atado ao passado anterior à cibercultura.

A partir de outubro de 2021, estudantes, docentes e funcionários retornaram fisicamente às instituições de ensino, as quais passaram a utilizar um formato híbrido, 
com parte do alunado revezando-se no remoto e outros no presencial.

Esse retorno também não tem sido muito fácil. Todos carregamos sequelas emocionais deixadas pela Covid-19, no entanto, como docentes de língua e literatura, é preciso unir a teoria à prática, numa permanente reflexão sobre o humano, retomando a citação de Antonio Candido (1995, p.180).

Resta uma certeza: nada voltará a ser como antes. O ensino híbrido, semipresencial, síncrono EAD (educação a distância) ou assíncrono vieram para ficar. O repertório apreendido por professores e alunos e o domínio das ferramentas digitais modificaram as práticas de ensino-aprendizagem. Pierre Lévy aponta a necessidade de grandes reformas nos sistemas de educação e formação:

Em primeiro lugar, a aclimatação dos dispositivos e do espírito do EAD [...] ao cotidiano e ao dia a dia da educação. O EAD explora certas técnicas de ensino a distância, incluindo as hipermídias, as redes de comunicação interativas e todas as tecnologias intelectuais da cibercultura. Mas o essencial se encontra em um novo estilo de pedagogia, que favorece ao mesmo tempo as aprendizagens personalizadas e a aprendizagem coletiva em rede. Nesse contexto, o professor é incentivado a tornar-se um animador da inteligência coletiva de seus grupos de alunos em vez de um fornecedor direto de conhecimento. (LÉVY, 2018, p.160)

O ensino de língua e literatura, assim como o de todas as demais áreas do conhecimento transformaram-se em um curto espaço de tempo, porém, os saberes estão postos e expostos nas redes. Trabalhar com o ensino, prática e reflexão sobre a produção de textos e a literatura abrem janelas capazes de ampliar horizontes e percepções, trazendo provocações, a fruição, o descobrir e redescobrir com outro olhar a cada releitura. $\mathrm{O}$ ato de ler, escrever e refletir sobre textos promove o diálogo e aguça os sentidos, e permite ver a realidade com outros olhos, criando, a partir do real, ou simplesmente desconectando-se dele, rumo ao inusitado mundo da imaginação, inovação e da interatividade.

Na prática de produção de textos para alunos do ensino superior, oportunizar a reflexão e a expressão de sentimentos como ansiedade, dor, medo e angústia gerados em consequência da pandemia esteve presente todo o tempo. Houve uma 
mudança na abordagem dos textos, isto é, O corvo, de Edgar Allan Poe, e Alice no País das Maravilhas, de Lewis Carroll, desencadearam reflexões sobre o momento vivido pelos alunos, pela sociedade.

A função docente como mediação neste processo foi fundamental no diálogo e no momento de trazer à tona as apreensões, criando textos e vídeos que permitissem uma autorreflexão por parte dos estudantes, como revelam os materiais produzidos.

No que diz respeito às práticas realizadas com os alunos do Ensino Fundamental II, os objetivos e resultados não foram diferentes. As produções artísticas, tanto verbais quanto não verbais, foram motivadas por conversas e estímulos a reflexões diversas. Os alunos foram incentivados a fazer um mergulho na própria história, percebendo que suas dores também eram as dores do outro, externando em palavras e imagens um pouco das dificuldades do momento em que estavam inseridos.

Às instituições de ensino cabe uma formação que vise a construção de saberes e identidades com habilidades e competências para construir uma sociedade mais justa e humana. O professor é uma importante peça nesse processo. Seu olhar aguçado, diante das dificuldades internas e externas que afetam o desenvolvimento dos estudantes, é fundamental na busca de caminhos que oportunizem o amadurecimento dos alunos.

O contexto da pandemia e pós-pandemia ainda gera muitas dúvidas e incertezas. Entretanto, através do uso de variadas formas e expressões da arte, professores constituíram ferramentas e percursos que provocam reflexões e evocam o entendimento capaz de lidar com os desafios prementes que afetam não só a todos os envolvidos no processo de ensino-aprendizagem, mas também a sociedade como um todo. 


\section{REFERÊNCIAS}

AGAMBEN, Giorgio. O Fogo e o Relato: ensaios sobre criação, arte e livros. Trad. Andrea Santurbano, Patrícia Peterle. São Paulo: Boitempo, 2018.

AGÊNCIA CÂMARA DE NOTÍCIAS. Educadores alertam para aumento de evasão escolar durante a pandemia, 06/10/2021. Disponível em: https://www.camara. leg.br/noticias/814382-educadores-alertam-para-aumento-de-evasao-escolar-durante-a-pandemia/ Acesso em 30 out. 2021.

ALUN.BE, Project. Disponível em: https://www.alunbe.com/edification\#0 Acesso 30 out. 2021.

BARTHES, Roland. Aula. Trad. L. Perrone Moisés. São Paulo: Cultrix, 1977.

CAMPBELL, Joseph. O herói de mil faces. São Paulo: Cultrix/Pensamento, 1999.

CANDIDO, Antonio. Vários Escritos. São Paulo: Duas Cidades, 1995.

CARROLL, Lewis. Alice no País das Maravilhas. Trad. Augusto de Campos. São Paulo: Nhambiquara, 2014.

CHEVALIER, Jean; GHEERBRANT, Alain. Dicionário de símbolos. Rio de Janeiro: José Olympio, 2006.

CNN BRASIL. "Pandemia aumenta evasão escolar, diz relatório do Unicef." Notícias CNN Brasil. Disponível em: https://www.cnnbrasil.com.br/nacional/2021/01/28/pandemia-aumenta-evasao-escolar-diz-relatorio-do-unicef Acesso em: 14/04/2021.

COELHO, Nelly Novaes. O conto de fadas: símbolos - mitos - arquétipos. 4ed. São Paulo: Paulinas, 2012.

CRIANÇAS DE IBEJIS. Conto e vídeo de Ananda Cantanhede Mota, Henry Alexandre Lobato Valencise, Nicole Oliveira da Silva, Thaís Stephanie Alves de Lima e Thauanny da Silva Batista. Trabalho desenvolvido para a disciplina de Interpretação e Produção de Texto do curso de Design de Mídias Digitais, $2^{\circ}$ semestre de 2020. Orientação: Profa. Dra. Sandra Trabucco Valenzuela. Fatec Carapicuíba. Disponível em: https://www.youtube.com/watch?v=IobbbVtPXhA Acesso em 30 out. 2021.

DIDI-HUBERMAN, Georges. Diante da Imagem: questão colocada aos fins de uma 
história da arte. Trad. Paulo Neves. São Paulo: Editora 34, 2013.

G1. Disponível em https://gl.globo.com/sp/sao-paulo/noticia/2021/07/23/evasao-escolar-dispara-durante-a-pandemia-e-cerca-de-670-mil-alunos-ficam-sem-estudar-em-sp-aponta-relatorio.ghtml Acesso em 30 out. 2021.

HOW GEORGE FLOYD DIED, AND WHAT HAPPENED NEXT. Reportagem. Disponível em: https://www.nytimes.com/article/george-floyd.html Acesso em 30 out. 2021.

IBGE. Pesquisa Nacional por Amostra de Domicílios - Pnad Covid-10, 2020. Disponível em: https://glo.bo/3jSi8fo Acesso em 30 out. 2021.

JUSTIÇA PARA GEORGE FLOYD. Reportagem. Disponível em: https://noticias.uol. com.br/reportagens-especiais/george-floyd-como-negro-morto-pela-policia-inspira-hoje-luta-antirracista/\#page1 Acesso em 30 out. 2021.

LÉVY, Pierre. Cibercultura. Trad. Carlos Irineu da Costa. 3ed. São Paulo: Editora 34, 2018.

MARTÍN VIDAL, Beatriz. Blog Beatriz Martin Vidal. Disponível em https://www.beavidal.com/blog Acesso em 14 abr. 2021.

MORAES, Odilon. Olavo. São Paulo: Jujuba, 2018.

MONO NO AWARE. Conto e vídeo de Anna Redistuo, Julia Mattos, Gabriely Melo, Gabriela Falleiros e Valéria Stephane. Trabalho desenvolvido para a disciplina de Interpretação e Produção de Texto do curso de Design de Mídias Digitais, $1^{\circ}$ semestre de 2020. Orientação: Profa. Dra. Sandra Trabucco Valenzuela. Fatec Carapicuíba. Disponível em: https://bit.ly/3kWZPpq Acesso em 30 out. 2021.

ORGANIZAÇÃO PANAMERICANA DE SAÚDE. Histórico da Pandemia de COVID-19. mar. 2020. Disponível em: https://www.paho.org/pt/covid19/historico-da-pandemia-covid-19 Acesso em 30 out. 2021.

OS SIMPSONS. "No Dia das Bruxas" ("Treehouse of Horror I”), EUA: Fox, 1990. Direção: David Silverman. Roteiro: Sam Simon, John Swartzwelder, Jay Kogen, Wallace Wolodarsky e Edgar Allan Poe.

PEIXOTO. José Luis. Regresso a casa. Porto Alegre: Dublinense, 2020.

POE, Edgar Allan. O Corvo. Trad. Fernando Pessoa e Machado de Assis. Org., posfácio e trad. dos ensaios Paulo Henriques Britto. São Paulo: Companhia das 
Letras, 2019.

SECRETARIA DA EDUCAÇÃO. Governo do Estado de São Paulo. Durante a Pandemia.

Disponível em: https://www.educacao.sp.gov.br/confira-decretos-e-resolucoes-de-educacao-implementados-durante-pandemia/, 02/07/2020. Acesso em 30 out. 2021.

VOGLER, Christopher. A jornada do escritor. Estruturas míticas para contadores de histórias e roteiristas. Tradução de Ana Maria Machado. Rio de Janeiro: Ampersand, 1997. 